\title{
20. State enterprise reform today
}

\section{Barry Naughton}

For almost 30 years after 1978, state-owned enterprise (SOE) reform was one of the central initiatives of China's overall economic reform (see Song, this volume). But during the mid-2000s, the impetus behind SOE reform stalled and little was achieved for almost a decade. It was a surprise to many, then, when the November 2013 resolution of the third plenum of the National Congress of the Communist Party of China (CPC) listed SOE reform as first among its substantive sections, raising hopes for a renewal of SOE reform. After a false start in 2014, activity accelerated in 2016, and initiatives and pilot programs have proliferated since. As of mid-2018, what are we to make of the present reality of and future prospects for SOE reform in China?

This chapter argues that the new measures are significant and will make China's SOE sector more financialised, but also more politicised. Corporate governance reforms are moving ahead that will finally corporatise all SOEs, divide them into public service and commercial types, and allow the process of 'mixed ownership' to take a step forward. Firms will be financialised in the sense that SOEs will increasingly be controlled by ownership agencies with a clearer financial structure and interest; simultaneously, many SOEs will be allowed to acquire financial interests in a range of new subsidiaries (including formerly private firms). However, at the same time, SOEs will be subjected to much more intrusive oversight by Communist Party committees and the Communist Party will be embedded in the corporate governance structure. This embedding is associated with an accelerating effort to enlist SOEs in the party's developmental agenda, which implies giving SOEs more tasks and responsibilities designed to further national strategies. These complex changes will affect SOEs in conflicting and perhaps contradictory ways, which make it difficult to project the outcomes. This complexity also makes it worthwhile to begin with a brief general discussion of some of the dilemmas implicit in public ownership.

\section{The impossible trinity}

All corporate governance systems must confront the problem of aligning the interests of managers with those of owners. Managers have day-to-day control of the firm's assets and can use them in ways not intended by the owners-for personal aggrandisement, risky ventures or even corruption. In a private firm, the 
owners generally have a predominant interest in profit, so the corporate governance problem can generally be reduced to the question of how to align the interests of managers with long-term profit maximisation.

Publicly owned enterprises have these problems, but face an additional complication: the public owner may have objectives additional to long-term profit maximisation. After all, if the public demanded nothing more than profit maximisation, why have public ownership at all? Privatisation would ensure efficient and profitable operation, and the public financial interest could be achieved either by taxation or by retaining a purely financial interest in corporatised firms. Cross-national research on SOEs has commonly found that although there is an efficiency penalty to public ownership, it can be quite small when such enterprises are properly incentivised, and China's experience shows that it is not necessary to prioritise privatisation of SOEs during the transition to a market economy. Most of the efficiency gains can be achieved by allowing entry to and improving the incentive structure of SOEs, just as China did between 1978 and 2005. However, this observation suggests a paradox. On one hand, SOEs can be nearly as efficient as private firms if government keeps a hands-off attitude and rewards efficiency and profit maximisation. On the other hand, if SOEs are to behave exactly like private firms, why bother to have stateowned firms at all (Qian 1996)? Yet Chinese policymakers have consistently declared that public ownership was necessary.

Through most of China's reform history, the conflict between profitability and other government-imposed objectives remained in the background. Worries about the low efficiency and poor incentives of SOEs led, in the 1980s, to a focus on improving incentives for managers so they would be motivated to improve profitability. In the 1990 _ - an era dominated by increasing market competition - this effort became all the more urgent, as improving performance and profitability became a matter of life and death for most SOEs. When the State-owned Assets Supervision and Administration Commission (SASAC) was formed in 2003, an embryonic profit recovery of the surviving SOEs was underway, but it still felt tentative and SASAC's early agenda was focused on improving profitability and corporate governance more generally (Naughton 2010, 2015). To be sure, this focus on profitability did not entirely exclude other objectives for SOEs. For example, Lin et al. (1998) argued that SOEs were a cost-effective way to provide employment and social benefits, justifying a gradual reform strategy. And local government officials certainly enjoyed having SOEs under their control, to help with employment, roadbuilding and other local projects. But the central government was preoccupied with a reform program that would improve profitability and performance, and all of the other actors recognised that these central goals ultimately overrode all other objectives, because SOEs were in a critical condition. These priorities drove SOE reform well into the 2000s. 
This state of affairs is no longer true today. SOEs became vastly more profitable in the 2000s, as restructuring, improved corporate governance and entry barriers created a more favourable operating environment. A psychological barrier was crossed in 2007, when central SASAC firms raked in RMB1 trillion in profits for the first time. The improvement in SOE profitability was not all efficiency gainsSOEs were increasingly concentrated in sectors where they retained some protection and they often had access to cheaper capital and inputs (especially land). However, careful studies of total factor productivity growth also show rapid rates of increase for incumbent state firms during this period (Brandt et al. 2012).

About this time, the central government became less concerned about profitability and began to ask SOEs to do other things as well. Especially when Wang Yong replaced founding head Li Rongrong as head of SASAC in 2010, the focus shifted to making SOEs 'big, strong' international champions and good public citizens. The fact that President Xi Jinping had, in 2009, at the fiftieth anniversary of the Daqing Oilfield, called SOEs 'an important foundation of Communist Party rule' also played a role in this shift (Xi 2009). When the Global Financial Crisis (GFC) hit at the end of 2008, policymakers were immediately concerned with using SOEs to boost domestic demand and lost any serious short-term interest in subjecting them to further financial discipline. With profitability no longer an urgent priority, SOE policy entered a period of drift, and the impetus for SOE reform faded noticeably between 2006 and 2009 .

When SOE reform was resurrected in the third plenum resolution in November 2013, it was in a policy environment that was radically different to that in the 1980s and 1990s. Chinese policymakers have come face-to-face with the trade-off between better incentives, stronger oversight and the assignment of developmental and political goals to SOEs. The most recent reform packages seem designed to achieve more of all three of these objectives. Improved incentives are back on the agenda because the deterioration of SOE profitability has become a renewed concern. Profits of central SASAC firms dropped during the GFC and again in the (global) decline in commodity prices in 2015-16. Even after significant recovery in 2017 , before-tax profits of central SASAC firms were only 2.6 per cent of gross capitaldown from 6.7 per cent in 2007. But if policymakers now want SOEs to be more profitable, they also want to exercise much more effective oversight and political control over SOE. Slack oversight of SOE managers in the 2000s had certainly contributed to a number of cases of serious corruption and abuse of power. The most egregious of these was that of Zhou Yongkang, who had created a corrupt network at the China National Petroleum Company-the most profitable central SOEand had then leveraged these resources into a personal political empire. Finally, the importance given to developmental and political goals for SOEs has also increased substantially. In particular, the importance of technology-oriented industrial policy has increased dramatically in recent years. While China has always had some kind of industrial policy, the recent effort is qualitatively different, because the scope, 
intensity and volume of resources involved is much higher than at any time in the past 40 years. Moreover, SOEs are supposed to play a big role in this policy. Thus, the current round of SOE reform differs from its forerunners in that policymakers hope to simultaneously achieve improvements in SOE incentives and governance, strengthened oversight and greater responsiveness to politically defined targets.

However, these objectives are at least partially contradictory and, to a certain extent, these three objectives should be thought of as an 'impossible trinity'. Policymakers can, in theory, achieve any two, but not all three. Profit incentives with strong oversight create a market environment governed by law and regulation. Multiple assigned objectives with strong oversight, on the other hand, leave little space for profit maximisation. Not only must managers scramble to meet multiple inconsistent targets; they must also use the trade-off among targets to deflect demands for rigorous profit maximisation. Multiple objectives are simply inconsistent with highpowered incentives (Holmstrom and Milgrom 1991). Finally, policymakers can assign multiple objectives and have weak oversight. This feasible-and commonly observed-outcome results in a kleptocratic state, as policymakers and SOE managers share the benefits of controlling public assets, allowing each to achieve their private objectives for as long as they serve the public. Clearly, Chinese policymakers today are not happy with any of these outcomes; they want to achieve more of all three objectives. In practice, that means trying to manage and minimise the trade-offs among the three, which is not an easy task.

\section{The reform process}

The difficulty of reconciling three competing policy objectives may explain the very uneven progress of SOE reform since the third plenum. During 2014, under the CPC's Leadership Small Group (LSG) on Comprehensively Deepening Reform, work on many aspects of SOE reform moved ahead quickly. There was intense debate and some occasional abrupt decisions, but the process seemed to be on track. Then, at the end of 2014, the process was suddenly put on hold and a new State Council LSG on SOE reform was set up, under the direction of state councillor Ma Kai. In September 2015, this LSG's general document on SOE reform was finally agreed to and ratified by the State Council and the central party (CPC and State Council 2015a). The document was couched in vague and occasionally contradictory terms, and it was understood from the beginning that multiple supplementary documents would also be required - a pattern the Chinese call ' $1+\mathrm{N}$ '. Within a year, 18 supplementary documents had been promulgated and, as a result, 2016 is often referred to as the first year of implementation for SOE reforms. Even so, most implementation in 2016 was described as 'pilot' or 'experimental'. The general approach was: as one pilot matures, complete it and move on to the next one. 
Between early 2016 and the beginning of 2018, an overall approach to SOE reform finally emerged. By this time, of course, SOE reform has broadly come to be viewed as disappointing (Batson 2016). Many people think nothing is happening. The reality - as this chapter will argue - is that quite a lot has happened and some of it has important positive potential. But the overall process of SOE reform has been hobbled by the effort to achieve contradictory objectives. Improvement in corporate governance has been real and reverses the disappointments of almost a decade of stagnation (2006-16). However, efforts to subject SOEs to greater oversight, and particularly to increase direct Communist Party intervention in SOE management, have profoundly undermined this progress. At the same time, the increased desire to assign SOEs multiple objectives, emphasising their status as part of the 'national team', has enormously complicated the effort to strengthen SOEs' incentives to increase efficiency and profitability. The basic argument of this chapter is that the pursuit of contradictory objectives has hobbled the recent program of SOE reforms and will continue to obstruct progress in the future.

The next three sections describe recent SOE reforms in three groups, related to the main policy objectives they are designed to pursue. First, in order to improve incentives and efficiency, policymakers sought to reinvigorate the reform of corporate governance, to make SOE managers more effectively motivated to improve firm performance. Second, in order to improve oversight, policymakers have greatly strengthened the role of the Communist Party and other oversight bodies. Third, in order to more effectively assign new missions and tasks to SOEs, policymakers have created new ownership agencies that are taking over tasks from the former SASACs. Of course, all the measures taken do not fit neatly into three boxes, and contradictory policy impulses are evident in each area. Together, these initiatives will likely improve SOE performance in some respects, but undermine it in others. The prospect is a state sector that is simultaneously more financialised and more politicised.

\section{Corporate governance reform}

The foundation of Chinese SOE corporate governance reform was laid out with the 1995 Company Law, which envisaged the conversion of traditional SOEs into corporations (in the lingo of the day, the 'modern enterprise system'). As part of a gradualist process, SOEs were to be converted by their owners, as they were ready, into one of a variety of corporate forms-joint stock, wholly state-owned corporations, and so on. This process went quickly for one category of SOEsthat is, profitable firms that could be listed on domestic or international stock exchanges, thereby immediately raising money (sometimes vast sums) for their owners. However, it went very slowly for less profitable firms and, especially, for the rather opaque 'apex corporations' under the central SASAC. These 100-odd firms 
had retained some of the characteristics of the industrial ministries from which they evolved, and had often held on to money-losing subsidiaries to permit their more profitable counterparts to list smoothly on stock exchanges. They were much less transparent than listed firms and in a position to hoard and redistribute resources among subsidiaries. What little progress was made converting these apex firms came to a halt after 2006-08 and, in 2010, less than half had been corporatised.

In the current wave of SOE reform, a push was mounted to corporatise all central SASAC apex corporations by the end of 2017. In fact, victory was declared-only 22 years after the initial Company Law. Of the 97 central SASAC apex corporations, 87 are said to have established boards of directors and 83 of these have a majority of external directors (Yin 2018). Among provincial SOEs, it is claimed 92 per cent have established boards of directors. Although it is clear some of the conversions were last-minute and rushed, full corporatisation is a prerequisite to revitalising SOE corporate governance reform. The establishment of authoritative boards of directors in newly corporatised SOEs was one of the constituent components of the 1990s reform that stalled in the mid-2000s and has now been revived.

The importance of corporate governance reform in practice depends to a significant extent on the next step of governance reform, which is the classification of firms into distinct categories as public service or commercial. The initial classification is a straightforward differentiation between commercial and public service firms, with public service firms providing goods and services in a price-regulated environment and with government maintaining sole or controlling ownership. These firms are primarily local utilities. Far more fraught is the designation within commercial enterprises of two sub-types. Enterprises whose main business is in fully competitive' sectors should accelerate corporatisation; they may raise money from outside investors, even allowing state ownership to become a minority position, and they should list on stock markets. Commercial enterprises in 'less-than-fully competitive' sectors, by contrast, as those in natural monopoly sectors or in business 'relating to national security, or the commanding heights of the national economy or important sector or keypoint areas'. These less-than-fully competitive firms should be incentivised to 'better serve important national strategies and macroeconomic control' and, specifically, 'develop forward-looking strategic sectors as well as any specially assigned responsibilities' (SASAC et al. 2015). Since many big SOEs have scores or even hundreds of subsidiaries, it is not at all straightforward which firms should go into which type, and there has been considerable friction around the designation of firms. All the central SASAC firms were reportedly divided into types by the end of 2014, only to have the slate wiped clean and the effort restarted in 2016. After much activity in 2016 and 2017, SASAC declared the process complete in all its enterprises at the central level and all 31 provincial SASACs. Yet, in contrast to the situation at the end of 2014, there has been absolutely no information released about how many firms fall into each category or which firms they are. There is quite 
a lot at stake. Firms that are designated 'fully competitive' have essentially received the go-ahead to become more autonomous. They may bring in outside investors, even allowing the state share to fall below 50 per cent. (They may not sell off state shares to outside investors; dilution is allowed only through raising new investment.) When the state share falls below 50 per cent, mixed-ownership firms escape salary caps that were imposed on chief executive officers (CEOs) in 2014. These firms are eligible to adopt market-based selection of managers, in which open recruiting and flexible salaries are to be the main elements. Thus, among the category of fully competitive commercial enterprises, the next step of 'mixed ownership' has the potential to be significant.

Mixed ownership has been a high-profile element component of the current wave of SOE reforms since 2013, without ever having been clearly or consistently defined. To be clear, mixed ownership has been a feature of the Chinese state sector for a long time, ever since state firms began to list on the stock market in the 1990s. Now, strategic 'private' investors are to be attracted into previously monopolised state sectors, and public-private partnerships have been advocated as a way of diversifying funding for infrastructure investments. An example of the potential of mixed ownership reform is provided by a local pilot, Yunnan Baiyao. This provincially controlled healthcare and pharmaceutical firm, which developed from a century-old traditional Chinese medicine company, took on two private strategic investors as part of a dramatic restructuring and expansion. The state share declined to 49 per cent, giving the firm far greater autonomy (Chu et al. 2018).

However, much greater limitations are evident in the first, highly publicised case of a 'mixed-ownership reform' of a central SOE_-that of Unicom, the number three telecom provider. In the summer of 2017, Unicom raised money from a consortium of 14 private sector investors, who injected RMB78 billion for a 35 per cent stake, potentially reducing the state's share to less than 50 per cent. However, the legitimacy of this restructuring was marred by suspicions that the investors had been herded into a compromise vehicle to provide Unicom with the prodigious sums necessary to roll out $5 \mathrm{G}$ telecom in the next few years. This rather clumsy process will only turn out to be a successful reform if the next steps of restructuring reveal a more dynamic and independent firm. In fact, these limitations are endemic in the current environment: truly private firms have been reluctant to participate in long-term contractual relations in which they have little bargaining power or legal protection. For example, most of the current public-private partnerships for which we have information are actually partnerships among different kinds of SOEs, not true private firms.

An interesting counterpart of private sector involvement in mixed ownership has been the determination to allocate 10 per cent of the existing state ownership to the Social Security Fund. Initiated in a few pilots in 2017, this program is to roll out for progressive implementation in all SOEs and financial institutions beginning 
in 2018 (State Council 2017). The significance of this for corporate governance is that it introduces a passive financial investor into the ownership structure who ought to have an interest purely in maximising share value. Another wrinkle in mixed ownership has been the enthusiasm displayed for employee stock ownership. Employee stock ownership programs (ESOPs) were begun in 2013-14, but then screeched to a halt at the end of 2014. Since 2016, 10 ESOP pilots have been moving forward again.

'Mixed ownership' also includes permission for SOEs to take stakes in private firms. Clearly, SOEs that have access to abundant cheap capital can use mixed ownership as a justification for expanding their control in the economy. The current wave of SOE reform clearly intends a strengthening of the state sector's effective presence in the economy. It does not countenance any privatisation or selling down of the state share. Of course, this is consistent with past policy, in which the CPC has insisted that public ownership should be the main body of the economy and state ownership should be the leading force, which must be consolidated and developed. But this attitude towards the state sector is being applied with much more consistency than in the past.

This discussion has made clear that the significance of corporate governance reform will depend significantly on what proportion of SOEs are placed in the 'fully competitive' type. For those placed in the 'less-than-fully competitive' type, their managerial autonomy will be significantly restricted. Once a firm is placed in this category, the government is supposed to maintain a controlling stake (CPC and State Council 2015a: Art. 5), and the managerial incentive contracts should be revised to reflect the special tasks and responsibilities assigned to the firm. Specifically:

'[W]hile giving appropriate weight to profitability and increased asset value, these firms should increase the weight given to examining conditions relating to serving national strategies, guaranteeing national security and the operation of the national economy, or developing prospective strategic sectors. (SASAC et al. 2015: Art. 2.4)

In other words, SOE reform specifically includes creating a category of SOEs that will stay state controlled and that will increase the attention given to political objectives and reduce the importance of profitability. Conversely, the new powers given to 'fully competitive'-type firms are significant. If a large majority of SOEs are placed in this category, the current wave of reforms may have some positive effect. If not, it is likely any positive effects will be more than vitiated by the impact of policies seeking to increase oversight and assign additional tasks to SOEs. 


\section{Enhancing oversight}

Efforts to improve oversight of SOEs have been a consistent theme of the past five years. President Xi's anticorruption campaign has, from the beginning, targeted SOEs as potential hotspots of corruption. The travelling inspection teams from the Central Discipline Inspection Commission have visited every central SOE, staying on site for several weeks to a few months, examining records and talking to a broad range of employees. In addition, new auditing mechanisms have been introduced and specific measures taken to guard against asset stripping and related party transactions.

By far the most important aspect of increased oversight has been the revived role for the Communist Party's leadership at every stage in the corporate governance mechanism. This new role is most clearly seen in the enterprise charter revisions that virtually every SOE carried out during 2017. Although these are not public documents, they circulate widely and their provisions are highly consistent, reflecting a set of top-down guidelines about the CPC's role in SOEs. These corporate charters incorporate the following provisions:

a. The CPC is formally embedded in the corporate governance system.

b. The chairperson of the board of directors should ordinarily be the first party secretary of the SOE.

c. Major strategic decisions of the SOE must be discussed first by the SOE CPC committee, and then passed on to the CEO. Both the board of directors and the firm management have an obligation to consult with the party committee before making important decisions.

These provisions reverse a fundamental tenet of Chinese SOE management that has been in place since the 1980s. Back then, the 'factory manager responsibility system' made clear that, in business matters, the factory manager (today's CEO), and not the party secretary, was the final decision-maker. That has been the predominant reality for the past 30 years. Now, the party secretary is once again the ultimate authority in SOEs. To be sure, there is a little ambiguity, due to the party secretary's dual role as chairperson of the board. The 'purpose', in a sense, of this arrangement is to prevent conflict between the chairperson of the board and the party secretary by uniting the roles in a single individual. Day-to-day management is still delegated to the CEO, who should maintain effective control of day-to-day decision-making. But obviously the scope for direct exercise of control rights by the party secretary is enormous. Moreover, the party secretary, by definition, is expected to execute CPC directives and national policies. His or her loyalty is to the party, rather than to the enterprise itself. This enhances oversight, but also creates new conflicts with managers, and makes it much easier for policymakers to assign multiple objectives 
to the firm. Indeed, the CPC is a special type of owner-one concerned with control rights only and with (usually) no claim on income streams. These missions are discussed in the next two sections.

\section{Defining SOE missions}

Over the past decade, Chinese policymakers have made more and more demands on state firms, which has led them to once again seek control rights. These demands are quite different from those in earlier years, and include using SOEs to spearhead China's development objectives. Today, these objectives include, most prominently:

1. Pioneering technological development. As Chinese development strategy shifts to innovation-led growth, SOEs have increasingly been called on to lead this process. More broadly, SOEs are expected to take a newly enhanced role in all industrial policies, from Strategic Emerging Industries to Made in China 2025.

2. Creating powerful national champions that will spread Chinese economic influence abroad. SASAC obsessively publicises the number of Chinese firms in the Fortune Global 500 list.

3. Maintaining macroeconomic stability by increasing investment when growth slows. Since 2009, when stimulus funds were channelled through SOEs to maintain aggregate demand, investment funding through SOEs has been a regular part of Chinese macroeconomic policy.

4. Leading sectoral and regional restructuring. In 2016, the promotion of supplyside structural reforms led to new responsibility being given to SOEs. The initial priority objective of this policy was to decommission excess heavy industrial capacity, and SOEs were asked to take the lead in organising capacity reduction cartels; now the policy has expanded into restructuring of other sectors, with SOEs still playing a prominent role. SOEs have also been asked to take the lead in the Belt and Road Initiative.

Chinese policymakers rarely display awareness of the importance of the competing objectives assigned to SOEs. Instead, with the revitalisation of the CPC under $\mathrm{Xi}$ Jinping, SOEs (like all state officials) are expected to be dynamic, bold leaders:

As the core force of national economic development, SOEs should play the leading function in supply-side structural reforms. They should carry out every aspect of reform in a model way, and become the pioneers and main force of the reform. (Xinhuanet 2016)

Changing the objectives assigned to SOEs inevitably means exercising control through different means. The next section describes the institutional changes in the exercise of public ownership. 


\section{The institutional exercise of public ownership}

A crucial part of the current wave of SOE reform since November 2013 has been the question of what type of institution should exercise public ownership rights. The current ownership agency, SASAC, is an evolutionary institution, established in 2004 to bring together previously dispersed ownership functions. SASAC has always struggled with limitations on its ownership rights and excessive regulatory mandates. The need to rationalise SASAC's complex bundle of income, control, supervision and regulatory powers has long been recognised. Since 2013, the proposed solution has been that of new state capital investment and operations companies (SCIOs). However, two competing conceptions of what these new investment companies should involve quickly emerged. The first was that the investment funds would operate as sovereign wealth funds, rather as they do in Singapore. It is easy to see that this approach is highly consistent with a view of state firms that sees maximising profit and improving efficiency as their predominant objectives. The owner focuses on residual income and the ownership agency is evaluated primarily on the financial performance of its portfolio. The Ministry of Finance proposed such investment companies in 2014, but their conception was discarded in favour of the creation of multiple investment funds with developmental objectives. That is, these funds would be expected to foster the creation of big competitive firms to develop emerging industries and to intervene in markets precisely to shape specific developments. This approach was developed in the proposals submitted by SASAC and wasnot coincidentally_-designed to be implemented by SASAC (at the national and provincial levels), which would gradually create SCIOs under its own auspices and transfer authority to them. ${ }^{1}$

This approach allowed SASAC to stay in control of the day-to-day creation and adaptation of new SCIOs. Eventually, SASAC's control rights may indeed pass to these SCIOs, but SASAC will directly manage this process. Multiple SOE reform documents - the ' $1+N$ ' process of specifying reform content-now refer to the role of these new ownership agencies. The SCIOs are explicitly instructed to exercise control functions more effectively, much more like an investment bank or a development fund than a wealth fund. The national funds are to have active restructuring roles:

1 This outcome is of course the result of the way the policy process was structured. The State Council LSG was headed by Ma Kai, a seasoned bureaucrat and former head of the erstwhile planning agency, the National Development and Reform Commission (NDRC), while its operational office was led by the head of SASAC. The top political leadership must have anticipated these outcomes when they created the LSG in this configuration (Chen and Naughton 2016). Xi Jinping and other top leaders must have consciously decided to endorse a conservative policy process in which existing agencies with a stake in exercising control rights would have the main voice in policy design. 
Push state capital into important industries and key sectors that affect national security, the commanding heights of the national economy and the people's livelihood; concentrate on keypoint infrastructure; concentrate on prospective strategic sectors; concentrate on outstanding enterprises with core competitive strength. Fully bring into play the SCIO companies to liquidate a batch of companies, reorganize a batch of companies, and innovate and develop a batch of companies ... Fully bring into play the core and exemplary function of SOEs in realizing the strategy of innovation-driven development and become a manufacturing power; strengthen the predominant position of enterprises in technological innovation; attach great importance to training scientific personnel and highly skilled personnel. (CPC and State Council 2015a: Art. 14)

By 2017, SASAC had begun pilots with 10 SCIOs, each created by expanding the powers of an existing SASAC subordinate firm. Provincial SASACs have created 50-60 subordinate SCIOs. There is theoretically some differentiation between state capital investment companies, which were instructed to remake themselves into financially oriented holding companies with subordinate investment funds and operational companies, and state capital operations companies, which previously gained experience in restructuring distressed assets and reorganising orphaned state firms. However, in practice, the difference between the two has blurred and both forms will be referred to here as SCIOs. The pilots demonstrate that SASAC has chosen familiar subordinate firms to serve as SCIOs precisely because they have the experience to more effectively exercise control rights and are closely tied to SASAC itself.

An example can help clarify the situation. One of the central SASAC's apex firms is Guoxin (or China Reform Holdings). It has long had a special status among SASAC firms as a specialist in restructuring other firms, and has now been designated a state capital operations company. Its expanded responsibilities include raising an 'industrial guidance fund'. These funds, which are proliferating in the Chinese economy, are set up with a managing partner (in this case, provided by Guoxin itself), along with several limited partners providing financing only. Guoxin has set up an industrial guidance fund called China Venture Capital (Guofengtou). True to its name, China Venture Capital invests both in start-up firms and in acquisitions. It is the sole owner of a Silicon Valley-based venture capital firm called Canyon Bridge Capital Partners, which made an offer to buy the American Lattice Semiconductor in 2017..$^{2}$ Clearly, Guoxin has seized substantial financial autonomy and has used it in creative ways. Equally clearly, that autonomy is dependent on Guoxin serving as an effective instrument for government policy —in this case, the building of China's semiconductor industry. In pursuit of that objective, nearly any kind of activity is permitted. This case also shows a SCIO exercising developmental policy through fully financialised instruments. All of Guoxin's subsidiaries, including China

2 The acquisition was blocked by the Committee on Foreign Investment in the United States (CFIUS). 
Venture Capital, are fully articulated corporate entities with clear incentives and responsibilities for the managing partner and the limited partners (although these are not on the public record). Indeed, even Guoxin itself is largely financialised, since it exercise a financial ownership stake in many firms without having the additional regulatory and command-and-control functions that SASAC had.

The creation of mission-oriented SCIOs is also apparent at the local government level. For example, Gansu province has incorporated most of its existing provincial plan into its new SOE reform program. Its new SCIOs are instructed to increase the amount of state capital in one of five named development zones, support provincial industrial policy and develop five strategic emerging industries: information technology, biopharmaceuticals, smart manufacturing, new energy and new materials. More than 80 per cent of the increase in state capital should be in 'strategic emerging industries, infrastructure, public services, and the externally oriented economy' (Gansu Provincial Department of Commerce 2016). Clearly, the SCIOs are expected to be developmental agencies.

The evolutionary and hybrid ownership institution SASAC is in the process of being replaced with new ownership institutions that can more aggressively and effectively exercise certain control rights. This rationalisation involves a sharper choice among alternative conceptions of the role of ownership agencies, and ends up supporting the focus on developmental objectives for SCIOs.

\section{Conclusions}

The current wave of SOE reform in China, while significant, is deeply troubled. To be sure, some of the inconsistencies in the current program simply reflect ordinary political compromises. Corporatisation with stronger boards of directors will give better transparency and clearer incentives, particularly in firms designated 'fully competitive'. This keeps reformers inside the politically enforced consensus and may provide them openings to push for better policies in the future. However, the overall program reflects the unmistakable victory of a political coalition that seeks to repurpose SOEs into developmental instruments. The choice of SCIO model reveals the preference of policymakers for a hands-on instrument that allows SOEs to be shaped into national champions and proactive shapers of development trajectories. This program is not likely to succeed. At the core of the problem is the 'impossible trinity' - the attempt to combine improved incentives, enhanced oversight and new missions for the SOEs.

First, SOEs are not likely to be effective instruments for the goals that policymakers are now assigning them. This is especially clear for the mission of becoming new technology pioneers. A large body of international experience demonstrates that entrenched incumbent corporations are bad at creating-and slow at adopting- 
radical innovation. Few of China's SOEs are concentrated in high-tech sectors. For example, China's largest SOE coalminer is now developing a large and expensive program of alternative energy research, which will probably be a huge waste of resources. It is difficult enough to use a single instrument to achieve multiple objectives, and the inevitable trade-offs become much worse when the instruments are an inappropriate choice for one or more of those goals. This will likely turn into an expensive failure.

Second, assigning SOEs multiple objectives creates problems for the improvement of incentives. A basic result of modern principal-agent theory is that high-powered incentives are appropriate in a situation where there is a single objective, especially if it can be effectively monitored in the short run. However, if an agent is assigned multiple objectives, low-powered incentives and long-term career rewards are typically more effective (Holmstrom and Milgrom 1991). This is because higher rewards attached to one objective will draw effort away from the other objectives; therefore, an agent's judgement is needed to allocate effort and effectively juggle the trade-offs among objectives. China in the past gave quite high-powered incentives to managers and local government officials, because there was an overwhelming consensus on the importance of economic performance during the high-growth era (1978-2010). In the contemporary era, longer-term and lower-powered incentives may indeed be more appropriate to a more complex bundle of social goals, but it is unlikely this will be achieved by simply rewriting managerial compensation contracts. Stronger incentives are desired to reduce 'slack' and the pursuit of private benefits, but this is unlikely to be achieved by simply assigning rewards to different targets.

Third, with the assignment of multiple objectives to SOEs, oversight will likely deteriorate. This is because bargaining over the outcome of multiple performance indicators is virtually inevitable. SOE managers, who have to trade-off time and resources devoted to different outcomes, always have an argument for special treatment. If a company's profitability is below its peers, but it has done an outstanding job of subsidising one technology or another, should it not be given a pass on profitability? With multiple objectives, it is more difficult to reduce agency loss through heightened monitoring. Although the current vigorous anticorruption campaign can temporarily deter some private exploitation of control rights, the fundamental space for such exploitation increases with these multiple objectives.

However, these shortcomings should not blind us to the important changes taking place in China's SOE sector. At a minimum, the system appears to be creating more efficient instruments to carry out China's industrial policy objectives. The Guoxin example shows this. Moreover, as financialised 'mixed ownership' structures become larger and more complex, the additional oversight exercised by the CCP and new audit agencies may become more necessary. Thus, the goal of achieving a more efficient instrument that serves the state's developmental interests is partially achievable. Whether this is compatible with a profound restructuring and increased 
efficiency of the broader state sector depends on the evolution of reform from this point forward. In particular, the scope of the classification of fully competitive commercial enterprises will have particular importance.

While it is too early to determine whether these reforms will be 'successful', or whether they will turn out to be market-oriented, the emerging institutions are significantly different from the traditional system. Change has been introduced by fairly conservative interest groups_-SASAC and the State Council SOE Leadership Small Group — which may indicate political limitations on the degree of expected change. Most important, there are important contradictions and tensions among the objectives of increasing oversight and giving firms more political and developmental missions, on the one hand, and improving their incentives, corporate governance, and financial flexibility on the other. Nevertheless, if local firms and ownership agencies are given sufficient leeway, and if the bulk of SOEs are reclassified as 'fully competitive commercial enterprises', these reform may lead to significant economic progress.

\section{References}

Batson, A. (2016), What not to expect from Chinese SOE reform, Blog, 21 September. Available from: andrewbatson.com/2016/09/21/what-not-toexpect-from-chinese-soe-reform/.

Brandt, L., Biesebroeck, J. V. and Zhang, Y. (2012), Creative accounting or creative destruction? Firm-level productivity growth in Chinese manufacturing, Journal of Development Economics 97(2): 339-51. doi.org/10.1016/j.jdeveco. 2011.02.002.

Chen, L. and Naughton, B. (2016), An institutionalized policy-making mechanism: China's return to techno-industrial policy, Research Policy 45: 2138-52. doi.org/ 10.1016/j.respol.2016.09.014.

Chu, M., Kirby, W. C., Hua Dai, N. and Wang, Y. (2018), Yunnan Baiyao: Transforming a Chinese state-owned enterprise, Harvard Business School Case N2318-078, rev. 20 March, Boston: Harvard Business School.

Communist Party of China (CPC) and State Council (2015a), Guiding opinions of the Central Committee of the Chinese Communist Party and the State Council on deepening the reform of state-owned enterprises, [in Chinese], Xinhuanet, 24 August. Available from: news.xinhuanet.com/politics/2015-09/13/ c_1116547305.htm. 
Communist Party of China and Central Office of the State Council (CPC and State Council) (2015b), Guiding opinions on promoting state-owned cultural enterprises to put social benefits first, and resolving social benefits and economic benefits together, [in Chinese], Xinhuanet, 14 September. Available from: news. xinhuanet.com/politics/2015-09/14/c_1116559409.htm.

Gansu Provincial Department of Commerce (2016), Practical Views on Deepening State Enterprise Reform, [in Chinese], 18 February, Lanzhou: Gansu Provincial Department of Commerce. Available from: gansu.mofcom.gov.cn/article/ sjshangwudt/201602/20160201257319.shtml.

Holmstrom, B. and Milgrom, P. (1991), Multitask principal-agent analyses: Incentive contracts, asset ownership, and job design, Journal of Law, Economics and Organization 7(SI): 24-52.

Lin, J. Y., Cai, F. and Li, Z. (1998), Competition, policy burdens, and state-owned enterprise reform, American Economic Review 88(2): 422-7.

National Bureau of Statistics (NBS) (2013), China Economic Census Yearbook, Beijing: China Statistics Press.

National Bureau of Statistics (NBS) (2015), Fixed Investment Statistical Yearbook, Beijing: China Statistics Press.

National Bureau of Statistics (NBS) (2016), China Statistics Yearbook, Beijing: China Statistics Press.

Naughton, B. (2010), China's industrial capitalism: Is there a distinctive system? Can it be a model for others?, Journal of Contemporary China 19(65) (June). doi.org/10.1080/10670561003666079.

Naughton, B. (2015), The transformation of the state sector: SASAC, the market economy and the new national champions, in B. Naughton and K. S. Tsai (eds), State Capitalism, Institutional Adaptation and the Chinese Miracle, New York: Cambridge University Press. doi.org/10.1017/CBO9781139962858.003.

Qian, Y. (1996), Enterprise reform in China: Agency problems and political control, Economics of Transition 4(2)(October): 427-47. doi.org/10.1111/ j.1468-0351.1996.tb00181.x.

State Council (2015), Several opinions of the State Council on reforming and perfecting the state-owned assets management system, [in Chinese], Guofa (63)(4 November). Available from: www.gov.cn/zhengce/content/2015-11/04/ content_10266.htm. 
State Council (2017), Notice of the State Council on printing and distributing the implementation plan of transferring some state-owned capital to enrich social security funds, [in Chinese], Guofa (49)(18 November). Available from: www.gov.cn/zhengce/content/2017-11/18/content_5240652.htm.

State-owned Assets Supervision and Administration Commission (SASAC) (2014), SASAC Yearbook, Beijing: SASAC.

State-owned Assets Supervision and Administration Commission (SASAC), Ministry of Finance and National Development and Reform Commission (2015), Views on Demarcating and Classifying SOEs, 29 December, Beijing: SASAC.

$\mathrm{Xi}$, J. (2009), Speech at the 50th anniversary of the discovery of Daqing Oilfield, [in Chinese]. Available from: news.cnpc.com.cn/system/2009/09/23/001259157. shtml (site discontinued).

Xinhuanet (2016), SOE development is facing unprecedented difficulties, [in Chinese], Xinhuanet, 10 June. Available from: finance.ifeng.com/a/ 20160610/14475324_0.shtml.

Yin, Y. (2018), The new situation and new responsibilities of SOE reform, [in Chinese], Xinlang Finance, 26 May. Available from: finance.sina.com.cn/ meeting/2018-05-26/doc-ihcaqueu4140308.shtml. 
This text is taken from China's 40 Years of Reform and Development: 1978-2018, edited by Ross Garnaut, Ligang Song and Cai Fang, published 2018 by ANU Press, The Australian National University, Canberra, Australia.

doi.org/10.22459/CYRD.07.2018.20 